\title{
Dextrose and Sorbitol as Diluents for Continuous Intravenous Heparin Infusion
}

\author{
JUDITH M. CHESSELLS, TESSA A. BRAITHWAITE, D. A. CHAMBERLAIN
}

British Medical fournal, 1972, 2, 81-82

\section{Summary}

A comparison of $5 \%$ dextrose and $5 \%$ sorbitol as diluents for heparin given by continuous intravenous infusion indicated that neither impaired the potency of the heparin. Previous suggestions that heparin becomes unstable in dextrose solution have not been confirmed.

\section{Introduction}

The use of heparin by continuous infusion in patients with recent myocardial infarction or impaired myocardial function may be attended by special difficulties, since it is desirable in such patients to avoid the infusion of saline. Five per cent dextrose has been criticized as a vehicle for the administration of heparin on the grounds that the anticoagulant may lose potency if it is in solution for any length of time at the relatively low pH of dextrose (Pritchard, 1964; O'Riordan and MacGowan, 1970). Presumably as a result of these statements, recent authoritative publications giving information on incompatibilities of drugs with infusion fluids have again stressed that heparin should not be diluted in dextrose (Drug and Therapeutics Bulletin, 1970; Girdwood, 1971). The Drug and Therapeutics Bulletin (1971) later issued a correction based on unpublished data stating that dextrose was a suitable diluent, and Stock and Warner (1971) supported this contention with in-vitro studies. However, it is clear that uncertainty on this point still exists, and no formal in-vivo comparison has been made of the anticoagulant effect of heparin diluted in dextrose and diluted in a fluid with a more normal $\mathrm{pH}$.

We now report the results of a within-patient cross-over trial designed to compare 5\% dextrose and 5\% sorbitol as diluents for heparin in patients with recent myocardial infarction.

\section{Patients and Methods}

The effects of heparin administered by continuous intravenous infusion were assessed in 10 male patients admitted to the coronary care unit with a diagnosis of recent myocardial infarction. Therapy with heparin was given for a total of nine days. All patients were given an initial intravenous dose of heparin 70 units per kilogramme body weight $(\mathrm{U} / \mathrm{kg})$; this was followed by a continuous drip infusion of heparin 20,000 units in $500 \mathrm{ml}$ of $5 \%$ sorbitol ( $\mathrm{pH} 6.2$; Servier Laboratories Ltd.) every 12 hours, using a paediatric drip set (McGaw Metriset). The dose of heparin was adjusted during the first three days of therapy to give a partial thromboplastin time with kaolin (P.T.T.K.) of 80-120 seconds; an identical daily dose of heparin was given over the following six days, but it was diluted in 5\% dextrose (pH 3.8 to 4.5, mean 4.13; Evans Medical Ltd.) $500 \mathrm{ml}$ every 12 hours for three days and in $5 \%$ sorbitol, $500 \mathrm{ml}$ every 12 hours for three days. The order in which these diluents were

Royal Sussex County Hospital, Brighton

JUDITH M. CHESSELLS, M.D., M.R.C.P., Research Assistant

TESSA A. BRAITHWAITE, M.B., B.S., M.R.C.P., Senior House Officer D. A. CHAMBERLAIN, M.D., M.R.C.P., Consultant Cardiologist used over the trial period was alternated so that five patients received dextrose first and five received sorbitol first.

In each patient the effect of heparin in vivo was studied during one sorbitol and one dextrose infusion (on Day 5 and Day 8). Blood was taken four times during a 12-hour infusion period (at 3, 6, 9, and 12 hours) for estimation of P.T.T.K. and plasma heparin level. These investigations were performed on citrated plasma by the methods described by Dacie and Lewis (1968). The normal range for P.T.T.K. is $30-45$ seconds.

In a further 20 patients continuous drip infusion of heparin was given into a peripheral vein about 2 in $(5 \mathrm{~cm})$ above the wrist with either dextrose or sorbitol for a period of eight days to compare the incidence of local phlebitis from the two diluents.

\section{Results}

Heparin Requirements.-The daily dose of heparin initially required to maintain the P.T.T.K. between 80 and 120 seconds ranged from 28,000 to 40,000 units (from 330 to $550 \mathrm{U} / \mathrm{kg} / 24 \mathrm{hr}$ ). No haemorrhagic complications were observed during the study.

Variations during Test Infusions.-Four measurements of both plasma heparin and P.T.T.K. were made during each of the 10 dextrose and 10 sorbitol test infusions. During each individual infusion there was little variation in the plasma heparin level; in only one infusion was variation as great as $1 \mathrm{U} / \mathrm{ml}$ observed during the $12-\mathrm{hr}$ period. More variation was observed in the P.T.T.K.; in one patient the difference between results at 3 and 12 hours was over 200 seconds. The P.T.T.K. and plasma heparin levels when dextrose was used as the diluent were not significantly different from those when sorbitol was the diluent (Table I). To determine if the heparin lost potency during the

TABle I-Comparison of Plasma Heparin Levels and Partial Thromboplastin Times at 3 and 12 Hours

\begin{tabular}{|c|c|c|c|c|c|c|c|c|}
\hline \multirow{3}{*}{$\begin{array}{l}\text { Case } \\
\text { No. }\end{array}$} & \multicolumn{4}{|c|}{ Dextrose Infusion } & \multicolumn{4}{|c|}{ Sorbitol Infusion } \\
\hline & \multicolumn{2}{|c|}{$\begin{array}{l}\text { P.T.T.K. } \\
\text { (Seconds) }\end{array}$} & \multicolumn{2}{|c|}{$\begin{array}{c}\text { Plasma Heparin } \\
(\mathrm{U} / \mathrm{ml})\end{array}$} & \multicolumn{2}{|c|}{$\begin{array}{l}\text { P.T.T.K. } \\
\text { (Seconds) }\end{array}$} & \multicolumn{2}{|c|}{$\begin{array}{c}\text { Plasma Heparin } \\
(\mathrm{U} / \mathrm{ml})\end{array}$} \\
\hline & $3 \mathrm{hr}$ & $12 \mathrm{hr}$ & $3 \mathrm{hr}$ & $12 \mathrm{hr}$ & $3 \mathrm{hr}$ & $12 \mathrm{hr}$ & $3 \mathrm{hr}$ & $12 \mathrm{hr}$ \\
\hline $\begin{array}{r}1 \\
2 \\
3 \\
4 \\
5 \\
6 \\
7 \\
8 \\
9 \\
10\end{array}$ & $\begin{array}{r}135 \\
240 \\
165 \\
145 \\
90 \\
150 \\
115 \\
160 \\
95 \\
150\end{array}$ & $\begin{array}{r}200 \\
90 \\
165 \\
380 \\
65 \\
105 \\
95 \\
105 \\
95 \\
95\end{array}$ & $\begin{array}{l}1.0 \\
1.5 \\
1.0 \\
1.5 \\
1.0 \\
2.0 \\
1.5 \\
1.0 \\
0.5 \\
1.0\end{array}$ & $\begin{array}{l}1.5 \\
1.5 \\
1.0 \\
2.5 \\
0.5 \\
1.5 \\
1.5 \\
1.0 \\
0.5 \\
1.0\end{array}$ & $\begin{array}{r}100 \\
180 \\
50 \\
110 \\
100 \\
160 \\
89 \\
220 \\
75 \\
95\end{array}$ & $\begin{array}{r}100 \\
80 \\
210 \\
140 \\
85 \\
140 \\
70 \\
145 \\
160 \\
80\end{array}$ & $\begin{array}{l}1.5 \\
2.0 \\
0.5 \\
1.5 \\
1.0 \\
1.5 \\
1.5 \\
1.0 \\
1.0 \\
1.0\end{array}$ & $\begin{array}{l}1.5 \\
1.5 \\
1.0 \\
1.5 \\
0.5 \\
1.0 \\
1.5 \\
1.0 \\
1.5 \\
0.5\end{array}$ \\
\hline $\begin{array}{l}\text { Mean } \\
\text { S.D. }\end{array}$ & $\begin{array}{r}144 \\
40\end{array}$ & $\begin{array}{r}139 \\
88\end{array}$ & $\begin{array}{l}1.2 \\
0.4\end{array}$ & $\begin{array}{l}1.3 \\
0.6\end{array}$ & $\begin{array}{r}118 \\
49\end{array}$ & $\begin{array}{r}121 \\
43\end{array}$ & $\begin{array}{l}1 \cdot 3 \\
0 \cdot 4\end{array}$ & $\begin{array}{l}1.2 \\
0.4\end{array}$ \\
\hline$t$ & \multicolumn{2}{|c|}{$0 \cdot 157$} & \multicolumn{2}{|c|}{$0 \cdot 38$} & \multicolumn{2}{|c|}{$0 \cdot 131$} & \multicolumn{2}{|c|}{0.86} \\
\hline
\end{tabular}

course of the 12-hour infusion period the plasma heparin levels and P.T.T.K. in samples of blood taken at three hours were compared with those in samples taken at 12 hours (Table I); no significant difference was observed between the two groups of samples. Thus there was no evidence that the potency of heparin decreased over a 12-hour period whether it was diluted in dextrose or in sorbitol.

Variations in Heparin Sensitivity.-To determine if the patients' sensitivity to heparin altered during the course of treatment the mean of the four plasma heparin levels on the 
first test day (Day 5) was compared with that on the second test day (Day 8). Results are shown in Table II. Mean plasma heparin levels were within the range $0.5-1.5 \mathrm{U} / \mathrm{ml}$ in 18 of the

TABLE II-Comparison of Mean Plasma Heparin Levels and Partial Thromboplastin Times on Day 5 and Day 8

\begin{tabular}{|c|c|c|c|c|}
\hline \multirow{2}{*}{ Case No. } & \multicolumn{2}{|c|}{ P.T.T.K. (Seconds) } & \multicolumn{2}{|c|}{ Plasma Heparin $(\mathrm{U} / \mathrm{ml})$} \\
\hline & Day 5 & Day 8 & Day 5 & Day 8 \\
\hline $\begin{array}{rl}1 & \text { S. } \\
2 & \text { S. } \\
3 & S . \\
4 & S . \\
5 & \text { S. } \\
6 & \mathrm{D} . \\
7 & \mathrm{D} . \\
8 & \mathrm{D} . \\
9 & \mathrm{D} . \\
10 & \mathrm{D} .\end{array}$ & $\begin{array}{r}101 \\
115 \\
89 \\
147 \\
98 \\
116 \\
92 \\
115 \\
100 \\
96\end{array}$ & $\begin{array}{r}115 \\
141 \\
190 \\
213 \\
100 \\
147 \\
75 \\
184 \\
112 \\
80\end{array}$ & $\begin{array}{l}1.5 \\
1.3 \\
0.6 \\
1.3 \\
0.9 \\
1.6 \\
1.3 \\
1.0 \\
0.5 \\
1.0\end{array}$ & $\begin{array}{l}0.6 \\
1.5 \\
1.0 \\
1.7 \\
0.8 \\
1.5 \\
1.5 \\
1.1 \\
1.1 \\
0.6\end{array}$ \\
\hline $\begin{array}{l}\text { Mean } \\
\text { S.D. }\end{array}$ & $\begin{array}{r}107 \\
16\end{array}$ & $\begin{array}{r}136 \\
45\end{array}$ & $\begin{array}{l}1.1 \\
0.3\end{array}$ & $\begin{array}{l}1 \cdot 1 \\
0.4\end{array}$ \\
\hline$t$ & \multicolumn{2}{|c|}{1.79} & \multicolumn{2}{|c|}{0.321} \\
\hline
\end{tabular}

S. = Patients given sorbitol first. D. = Patients given dextrose first.

20 infusions; the P.T.T.K. was in the range $80-120$ seconds in 14 out of 20 infusions. Plasma heparin levels were higher on Day 8 than on Day 5 in six patients and lower in four. The mean P.T.T.K. was higher on Day 8 than on Day 5 in eight patients and lower in two. The changes in P.T.T.K. did not reach a level of statistical significance $(0.1>P>0.05)$. Because of the change in the infusion fluid between Day 5 and Day 8, the results were analysed separately according to the type of fluid given first; again no significant differences emerged.

Incidence of Thrombophlebitis. - Ten patients had constant drip infusion of heparin in dextrose for eight days; one developed phlebitis on the sixth day. Of the 10 patients who received heparin in sorbitol two developed phlebitis on the fourth infusion day. This relatively small incidence of phlebitis might have been due in part to the low infusion rates.

\section{Discussion}

The results of this investigation suggest that both $5 \%$ dextrose and $5 \%$ sorbitol are suitable diluents for heparin by constant drip infusion. Pritchard (1964) reported that heparin became unstable when autoclaved at $\mathrm{pH}$ below 5 and suggested that the anticoagulant might lose its potency when mixed with dextrose. Since then it has been suggested, without actual experimental proof, that dextrose is an unsuitable diluent for heparin. However, our results indicate that the effectiveness of a heparindextrose solution does not alter during a 12-hour infusion period. If loss of potency of heparin had occurred, one might expect to find less effective heparinization-that is, a shortened P.T.T.K. and lower plasma heparin level in samples of blood taken at 12 hours than at three hours; we found no difference between such samples. We cannot, of course, rule out the possibility that some decrease in potency may occur with solutions of dextrose at a lower $\mathrm{pH}$ than the range we were using (3.8 to 4.5$)$, but the lower limit of the B.P. specification is set at 3.5 .
Despite careful control of the infusion some variation in plasma heparin level and a wider variation in P.T.T.K. were observed during the 12 -hour period. Some variations may occur even when heparin is administered by constant infusion pump, although Handley (1967) showed that the use of such a pump maintains a more consistent prolongation of the whole blood clotting time.

The initial level of P.T.T.K. in the present study (80-120 seconds) was longer than that advocated by some writers (Spector and Corn, 1967; Hirsh et al., 1970). During the test infusions even longer times were observed but no episode of bleeding occurred in any patient. Plasma heparin levels remained, with two exceptions, within an acceptable range of $0.5-1.5 \mathrm{U} / \mathrm{ml}$. The two tests do not, of course, measure the same aspects of heparin activity in the blood; the difficulties of correlating various methods of control of heparin therapy have been discussed by Pitney et al. (1970). The results of the present study suggest that satisfactory plasma heparin levels may be accompanied by a P.T.T.K. outside the generally recommended range.

No constant pattern of heparin requirements emerged; heparin dosage was not closely related to body weight. Despite the trend towards prolongation of the P.T.T.K. at eight days compared with five days, there was no acceptable evidence that the patients had become increasingly sensitive to heparin. These findings are in keeping with those of Pombo et al. (1970), who were unable to find any consistent change in heparin requirements during the two weeks following myocardial infarction.

Adjustments of dose are necessary to maintain consistent prolongation of the P.T.T.K. during treatment; the pattern of such adjustments is not predictable without laboratory control. Judging by the findings in the present study, the widespread practice of giving a constant dose of heparin (often 40,000 units daily) by intravenous infusion may result in overdosage, and theoretically runs the risk of haemorrhage. With adequate laboratory control heparin can be used satisfactorily as a continuous infusion, and both dextrose and sorbitol are suitable as diluents when it is necessary to avoid the use of saline.

We are grateful to Weddel Pharmaceuticals Ltd. for assistance with equipment, and to Servier Laboratories Ltd. for supplies of $5 \%$ sorbitol. J.M.C. was supported by a research grant from the South-east Metropolitan Regional Hospital Board.

Requests for reprints should be sent to Dr. D. A. Chamberlain.

\section{References}

Dacie, J. V., and Lewis, S. M. (1968). Practical Haematology, p. 256. London, Churchill.

Drug and Therapeutics Bulletin, 1970, 8, 55

Drug and Therapeutics Bulletin, 1971, 9, 24

Girdwood, R. H. (1971). Scottish Medical fournal, 16, 350.

Handley, A. J. (1967). British Medical fournal, 2, 482.

Hirsh, J., O'Sullivan, E. F., Gallus, A. S., and Martin, M. (1970). Australasian Annals of Medicine, 4, 334

O'Riordan, J., and MacGowan, W. (1970). Lancet, 2, 521.

Pitney, W. R., Pettit, J. E., and Armstrong, L. (1970). British Medical fournal, 4, 139.

Pombo, J. F., Russell, R. O., and Foster, G. L. (1970). Archives of Internal Medicine, 126, 1000 .

Pritchard, J. (1964). Fournal of Pharmacy and Pharmacology, 16, 487.

Spector, I., and Corn, M. J. (1967). Fournal of the American Medical Association, 201, 157.

Stock, S. L., and Warner, N. (1971). British Medical fournal, 3, 307. 